\title{
Local Wisdom and The Threat of Extinction in Kitchen Appliances of Minangkabau Lexicons
}

\author{
R Almos ${ }^{1}, \mathrm{~S}$ Ladyanna ${ }^{2}$ \\ \{1 ${ }^{1}$ ronaalmos@hum.unand.ac.id, ${ }^{2}$ ladyannasonezza@ hum.unand.ic.id \\ ${ }^{1,2}$ Andalas University Padang, Indonesia
}

\begin{abstract}
Kitchen appliances the Minangkabau society has undergone many changes. This change resulted in the lexicon being used also changing. The classic Minangkabau society has a typical cooking lexicon like pangua 'grater'. This equipment is no longer used by the Minangkabau community. This results in the extinction of the lexicon. The purpose of this study is to explain the meaning and local wisdom of the classic lexicons and the threat of extinction of the lexicon of cooking equipment. Data from this study comes from text edits and documentation of Minangkabau folklore. In analyzing the data, the researcher used a method equivalent to anthropolinguistic theory. Based on the results of the study it can be concluded that the lexicon of cooking equipment in classical Minangkabau culture can be grouped in the form of names of cooking tools and cooking containers. The lexicon above is hardly used anymore and has been replaced with modern equipment so that the lexicon is threatened with extinction and results in the breaking of the local wisdom inheritance chain.
\end{abstract}

Keywords: Lexicon, Extinction, Cooking Utensils, Minangkabau

\section{INTRODUCTION}

There are many tools make human task get easier. Cooking has become a basic necessity for human beings, since food is one of basic human needs. Until now, the cooking equipment being used is still a hand tool. However, everyone has slightly high activity. The presence of cooking tools that can do the cooking work by itself is now necessary [1]. Traditional cooking utensils are part of household appliances that are almost owned by every ethnic group in the world. Traditional kitchen equipment is a legacy of knowledge, creativity, skills and technology in a society. Such equipment continues to change along with technological developments that accompany human civilization. From these changes, several kitchen utensils have not been used and replaced with other equipment that is more effective, especially in use and time of use, according to the lifestyle of this modern society.

This will lead to changes in the use of lexicons in the community. Technology changes that have resulted in changes in equipment used will have an impact on people's knowledge. Community knowledge will influence the lexicon that is understood by the community. If an equipment is no longer used by the community, then the equipment will rarely be seen, and over time the lexicon will also be no longer known by the community. The loss of a lexicon is a threat to the retention of a language that has an effect on the inheritance of local wisdom of a community.

Changes in the use of kitchen equipment also occur in the Minangkabau community. The Minangkabau community has also developed so that some traditional equipment is no longer used and replaced with more effective and futuristic equipment. This change resulted in the shifting of the lexicon used by the community. The lexicons of traditional equipment are 
classic lexicons because they are rarely even used anymore. Many classic Minangkabau lexicons that have experienced change and even extinction [2]

One of them occurs in the pangua lexicon, whose reference is used by traditional communities to grate coconut meat. The development of technology presents a more effective and efficient coconut grater machine so that people prefer a greater machine that is operated using electricity. However, cultural values will not be obtained from a greater machine. The use of pangua in cooking in large quantities, especially in welcoming important days, will involve many family members so that the values of mutual cooperation in a family or community continue to be established. Meanwhile, the use of grated machines does not require the involvement of many people because electricity has replaced human power.

Thus, pangua holds the value of the local wisdom of the Minangkabau people especially in togetherness when cooking. If this lexicon is not preserved, this lexicon will disappear so that the Minangkabau language will be eroded. Therefore, research on classical lexicon is very important so that the threat to language retention is no longer a frightening threat to the preservation of a language. Based on this, in this article, it is explained about the meaning of the classic lexicon of kitchen equipment and local wisdom contained in the lexicon. In addition, it also describes the threats to language retention, especially lexicons of cooking utensils.

Research on the Minangkabau lexicon has also been carried out by Reniwati [3] in which Reniwati divides the lexicon into two types, the lexicon that is almost lost and that has been lost without focusing on the field of use of the lexicon. Furthermore, Sonezza Ladyanna, et al. Discussed the lexicon of rice fields in the city of Padang which is also a region of Minangkabau culture with the result that the lexicon must be preserved so that local wisdom can continue to be inherited [4]

\section{RESEARCH METHOD}

This research is descriptive library research to explain and observe the symptoms of the language being studied. Data from this study comes from text edits and documentation of Minangkabau folklore. So, lexicons are obtained from edits of the manuscript and documentation of folklore with the theme of Minangkabau Culture. In addition, data was also obtained from interviews with informants who were traditional leaders in the Minangkabau Culture community. Thus, the cultural values in the lexicon can be fully described.

In analyzing the data, the researcher used a method equivalent to anthropolinguistics theory. Anthropolinguistics is a study of language as a cultural resource and speech as a cultural practice [5] So, the culture stored in the human mind as shared knowledge serves to explain the meaning of speech as a cultural practice. Palmer stated that anthropolinguistics is a name that tends to contain broad understanding in terms of language and culture [6].

\section{RESULTS AND DISCUSSIONS}

Lexicon cooking utensils in classical Minangkabau culture can be grouped in the form of cooking tools and cooking containers. Lexicon cooking tools found include pasu, salayan, parian, pangua, taku, garudan, and caruak. Lexicon cooking containers found are kapuran, balango, manggu, kumbuak, borasan, and laka. 


\subsection{Lexicon of Cooking Tools}

Cooking tools are tools used in the processing of food ingredients until they are cooked. The tools used are not used on the stove [7]. Lexicon cooking tools found include pasu, salayan, parian, pangua, taku, garudan, and caruak.

\section{Pasu}

Pasu is one of household appliances made of large and wide wood, made in such a way as to form a bowl-like container with a height of $15 \mathrm{~cm}$ long $35 \mathrm{~cm}$ wide and $19 \mathrm{~cm}$ wide. Round shape with the wall slightly stretched out, wide mouth, and thick lips. This market can be used as a place to squeeze coconut, wash vegetables, and so on. Pasu comes from the Payakumbuh area.

\section{Salayan}

Salayan is a kind rectangular place, made of bamboo. Salayan is located right above the stove. Salayan serves as a storage place for wood and kitchen tools. Besides that, Salayan functions as a wood drying place.

\section{Parian}

Parian is a place to store clean water for cooking. Parian is made of bamboo with a length of 1.5 meters. Long tube-shaped dance.

\section{Pangua}

Pangua is a tool used to grate coconut when cooking curry and other dishes using coconut milk. Pangua is shaped like a swan's neck, with size eyes on the head. The eye size is flat round and the edges are jagged. Grater is taped or seated on a square wooden board.

5. Taku

Taku is a tool used to make traditional food called kareh-kareh. Kareh-kareh is one of the traditional foods at the ceremony in Koto Gadang Village. Taku is made of coconut shell at the end, then the "shell eye" is removed so that the shell becomes smooth. Then, given a long handle and the shell is pierced with a small size.

\section{Garudan}

Garudan is made of wood or zinc which serves to grate cassava when cooking some traditional foods such as talam cake, lapek, and so on. Garudan has a flat rectangular shape covered with zinc sheets with holes as grated eyes. Rough hole marks on the outside function as a grater.

\section{Caruak}

This cooking tool is made from a coconut shell which is cleaved and then finely scraped. In the base and middle, given a hole to install the handle. Caruak is used to scoop up the water that has been cooked and the stalk is used to stir the rice in a pot so that the rice mixes. This tool is shaped like a water dipper or a large round spoon with a long handle.

\subsection{Lexicon of Cooking Containers}

A cooking container is a place to put or store cooking ingredients. Lexicon cooking containers found are kapuran, balango, manggu, kumbuak, borasan, and laka. 


\section{Kapuran}

Kapuran is a kind of container made of brass. A cylindrical body and a lid. The middle part of the lid of this container is pierced to place the air out. This container has a flat base and the top is closed slightly sloping. This tool has a yellowish and plain color. The function of this tool is as a place for whiting (sadah). Kapuran comes from the City of Padang, West Sumatra with a size of $6 \mathrm{~cm}$ high, and an upper middle line of $6 \mathrm{~cm}$.

\section{Balango}

Balango is a type of container made of clay which is mixed with fine sand with a certain process. This container is used as a tool for cooking curry. For people who live in rural areas, they prefer to use this balango for gouging rather than using containers made of aluminum. The community thinks that curry dishes made using balango will taste more delicious and steady than using aluminum.

Apart from being used for gouging, it can also be used as a place to make "palai", a way to cook food by wrapping the ingredients with banana leaves, then putting them in balango and cooking with fire until the banana leaves are scorched. Thus, the palai will ripen.

In addition, balango is also often used for "mamangek" which is a kind of curry but does not use coconut milk, which is used only a little water with ground chili and special cookers. This balango comes from the Galogandang area, Batusangkar, with a height of 12 $\mathrm{cm}$, with a medium mouth line of $27 \mathrm{~cm}$.

\section{Manggu}

Manggu is a kind of container made from a mixture of clay with fine sand and burned through a certain process. The shape is rather rounded, has legs, body and mouth. Manggu serves as a place to bring water from a well or from a spring to the house. The round body part is coated with embalau (a type of wood sap), with the intention that the container can be durable, not easily broken and look more shiny.

In the upper part of the body, given a decorative shape in the form of lines that circle around it. In the neck, there are also rhombus and triangle decorations. This container is used by upholding it above the head and usually the women use it. Manggu is from the Galogandang area, Batusangkar, with a height of $32 \mathrm{~cm}$, a medium leg line of $17 \mathrm{~cm}$, a medium line of $44 \mathrm{~cm}$ body, and a midline mouth of $31 \mathrm{~cm}$.

\section{Kumbuak}

Kumbuak is a form of pottery craft made from a mixture of clay with fine sand and then burned through a certain process. This tool is almost like the shape of a jug, has a handle. The bottom of the tool is bigger than the top (mouth) with a rather blackish color and on the body there are shadows of lines made with pelanggiah stones.

This herb is used as a place to store drinking water and sometimes the water is boiled (cooked) in that place. Kumbuak comes from the Balai Talang area, Payakumbuah with a height of $22 \mathrm{~cm}$, and a medium line of body $20 \mathrm{~cm}$ and a middle mouth $9 \mathrm{~cm}$.

\section{Borasan}

Borasan is a type of container used for storing rice to be cooked. Because of its function as a place to store rice, the community is called "wasteful". Borasan can be easily erected even though it is round in shape, has erect and circular lips because the outer side is given a circular foot. This drill is usually placed in the kitchen or in the room. When this device is not in use, put a round stone the size of an adult fist. What is the function of the 
round stone can not be known with certainty. Borasan comes from the Galogandang area, Batusangkar with a height of $35 \mathrm{~cm}$, a medium line of mouth $22 \mathrm{~cm}$, and a medium line of feet $20 \mathrm{~cm}$.

\section{Laka}

Laka serves as a place to put pottery pots. Laka is made from plant roots woven. In addition, there are also containers made of woven sticks. The shape of this container is half round. Laka has a diameter of $27 \mathrm{~cm}$ and a height of $9 \mathrm{~cm}$.

Referrals from the lexicon of cooking utensils and containers in the Minangkabau cultural community have hardly been used anymore so the lexicon has become a classic especially for the younger generation. Meanwhile, the lexicon has cultural values that contain local wisdom. As stated in the introduction, the pangua reflects mutual cooperation in the togetherness of a family or community in cooking food especially on certain days that require large amounts of food. The use of modern tools that do not require a lot of human labor results in a sense of individuality so that togetherness becomes increasingly vanished.

In general, traditional tools are made from natural materials that are easily available in the community, such as bamboo, wood, coconut shell, clay, and plant roots. The use of natural ingredients is very good for health, unlike the use of modern materials such as plastic which can endanger health. In addition, the absence of the use of electricity reflects a life that is environmentally friendly. The use of natural ingredients from the natural environment itself reflects the wisdom of the Minangkabau people in utilizing nature for a better life.

Local wisdom in the lexicon of cooking equipment and containers in this article is an important cultural heritage for the next generation. However, the development of cooking technology and lifestyle has resulted in changes in community needs in activities so that traditional equipment is not used anymore. When a referen lexicon is no longer used, then the lexicon will be rarely used and will eventually result in extinction. The extinction of the lexicon will gradually threaten the retention of a regional language. The threat to the retention of a regional language will result in weak inheritance of local wisdom.

Thus, research on classical lexicon is very important to develop. Some experts have also developed research on lexicons such as Herdara which examines Japanese people's cooking equipment. Japanese people also use unique and unique cooking equipment. First, the hocho cooker, is a knife made of steel but light that serves to cut sushi, sashimi, and others. Second, makisu is a small bamboo mat that is waterproof and flexible. The tissue is used to roll the rice perfectly. This bamboo mat has a length and width of $25 \mathrm{~cm} \mathrm{X} 25 \mathrm{~cm}$. Third, zaru is a woven basket made of bamboo that is used to separate food from hot water. Japanese people believe what if the basket is made of metal will reduce the quality of the taste of vegetables and food.

This has the same concept with the Minangkabau people who think the use of clay is better for food taste than the use of aluminum and other metals. Fourth, suribachi and surukogi, this tool is similar to playing on the kitchen equipment of the Indonesian people. However, the difference between cobekan is made of stone while suribachi and surukogi are made of sansho wood, Japanese pepper. This tool is used to grind grains, spices and grind pastes. Fifth, chasen is a traditional tea made from bamboo. This tool is very important in making matcha [8].

Another study related to this article is the research conducted by Muh. Akbar. In his research, researchers classified kitchen equipment based on ethnicity in Indonesia. In the Batak community, there are several kitchen utensils, including punutuan, namely containers where the spices will be ground and tutu are stone or wood seasoning grinders. Dental equipment is a type of cylindrical wood made of wood or woven pandanus. Furthermore, 
there is a tano hudon in the form of a vessel made of clay. Hobon is a large, very large barrel made of bark and serves as a place to store rice. Then, poting is a container made of clay and the lid is made of wood. This container serves as a place for wine [9].

Furthermore, research conducted by Kim Kwang On. In his research, he wrote the three things,first, regarding the history of the kitchen, second, where the gods lived in each house and third, the variety of furnaces and chimneys: from Korea to Japan. In the third part, he mentioned the fire stove for Japanese people was named after us while for the Korean people to wait for the fire to be named buttumak [10]. In Korea, heater for cooking is called sotduck [11]. While the traditional kitchen position in Cheongju City is located in front of nalgaechae [12]. In India, people cook using traditional stoves. The traditional Indian stove is called the chulha stove. When using chulha, it emits thick smoke which pollutes their kitchen utensils and clothes [13].

Unlike other countries, in Rusia and United Kingdom kitchen utensils have their own superstition such as glass, spoons, nad knives. A broken glass will bring happiness in marriage. However, if the glass of wine breaks there will be death. Meanwhile, the knife is considered as a protection [14]. Another research related to this article is the research that discusses about a new kitchen in Iran which is an ideologically and politically influential space. Iranians renovate their kitchens into open kitchens [15].

Thus, every culture has traditional cooking tools made from natural ingredients. Technological advancements change people's lifestyles which affect the use of cooking tools. Traditional tools begin to leave, threatening the loss of the lexicon from these devices. Lexicon is an asset of language and culture that must be preserved to avoid overlapping the inheritance of local wisdom to the next generation. Therefore, it is fitting for research on lexicons to be activated.

\section{CONCLUSIONS}

Based on the above analysis, it can be concluded that the lexicon of Minangkabau cooking utensils can be grouped into two groups, namely the cooking tool lexicon and the cooking lexicon. Lexicon cooking tools found include pasu, salayan, parian, pangua, taku, garudan, and caruak. Meanwhile, the lexicon of cooking containers found are kapuran, balango, manggu, kumbuak, borasan, and laka. The Lexicon above is hardly used anymore. One reason is because the cooking tools and cooking containers have been replaced with modern equipment. so the lexicons cannot be inherited and result in the loss of referrers from the lexicon. The extinction of a lexicon can result in breaking up the local wisdom inheritance chain. Thus, research on the classical lexicon of a culture can help maintain a language.

\section{ACKNOWLEDGMENT}

Thank you to the Direktorat Jenderal Penguatan Riset dan Pengembangan Kementerian Riset Teknologi dan Pendidikan Tinggi Republik Indonesia who has supported this research with the contract number 051 / SP2H / LT / DRPM / 2019 fiscal year 2019. Thank you also to the Lembaga Penelitian dan Pengabdian Universitas Andalas, Jurusan Sastra Minang, Fakultas Ilmu Budaya, Universitas Andalas, which has provided assistance and facilities in this research related to the study of classical text. 


\section{REFFERENCES}

[1] J. M. Welsh and P. (eds) Lev, The Literature/Film Reader, Issues of Adaptation. Lanham, Maryland - Toronto - Plymouth, UK: Scarecrow Press, INC., 2007.

[2] R. Almos, Pramono, H. N. Hidayat, and Seswita, "Teks klasik sebagai Sumber Pengembangan Leksikografi," Wacana Etn., vol. 6, No 2, pp. 91-96, 2017.

[3] Reniwati, "Leksikon yang (Hampir) Hilang Bahasa Minangkabau," in International Conference of Linguistics, Paling, 2018.

[4] S. Ladyanna, R. Almos, H. N. Hidayat, and Seswita, "Leksikon Persawahan di Kota padang," Puitika, vol. 14, 2018.

[5] A. Duranti, Linguistic Antropology. Cambridge: Cambridge University Press, 1997.

[6] Palmer, Toward a Theory of Cultural Linguisyics. Austin: University of Texas Press, 1996.

[7] "Pengertian dan Jenis- jenis Alat Memasak," 2017. [Online]. Available: http://amirajasaboga.blogspot.com/.

[8] Andira Herdara, "5 Peralatan Dapur yang Unik," 2017. [Online]. Available: https://japanesestation.com/5-peralatan-dapur-jepang-yang-unik/.

[9] Muh. Akbar, "Sistem Peralatan dan Perlengkapan Hidup berbagai Suku di Indonesia," 2014. [Online]. Available: http://muhakbar-syukur.blogspot.com/2014/08/sistemperalatan-dan-perlengkapan-hidup.html.

[10] Kim Kwang On, "Sebuah Pohon Keluarga: Dapur Cina, Korea, dan Jepang," Koreana, korea Cult. dan Arts, vol. Fitur Khus.

[11] B.-A. J.-L. Kim, International journal of human ecology., vol. 4, no. 1. Korean Home Economics Association, 2003.

[12] H.-R. T.-Y. Kim, "A Research on the Spatial Change of the Main Room and Kitchen of traditional Utbangkkeokeum House in Cheongju City," J. Korean Hous. Assoc., vol. 20, no. 6, pp. 19-29, 2009.

[13] Y. Wang and R. Bailis, "The revolution from the kitchen: Social processes of the removal of traditional cookstoves in Himachal Pradesh, India," Energy Sustain. Dev., vol. 27, pp. 127-136, Aug. 2015.

[14] E. Fliginskikh, S. Yakovleva, K. Vavilova, T. Soldatkina, and M. Naletova, "Household Items in the Folk Ritual Superstitions of the English, Russian, and Mari Languages," in Proceedings of the 2nd International Conference on Education Science and Social Development (ESSD 2019), 2019.

[15] E. Lor Afshar, "Form and Forces of Open Kitchens: The Secularization of Beauty and Private Space in Post-Revolutionary Iran," SSRN Electron. J., Apr. 2018.

[16] K. Saddhono, "Language and superdiversity: Indonesians knowledging at home and abroad. By Zane Goebel." Soc. Stu. vol. 12 no.1 pp. 113-118, 2018 